Journal of Educational Method and Technology Vol. 1 No. 2, September 2018

P-ISSN 2622-8459 E-ISSN 2622-8467

http://ejournal.unima.ac.id/index.php/jemtec

\title{
Simulation Method In Programmable Logic Controller
}

\author{
J M Sumilat ${ }^{1,}$ F R Seke', JMantiri ${ }^{3}$ \\ 1, 2, 3 Universitas Negeri Manado, Indonesia \\ corresponding aunthor: ${ }^{1}$ julianasumilat@unima.ac.id
}

\begin{abstract}
Programmable logic controller (PLC) is a microprocessor used to automate industry processes such as controlling a factory's engine. As a candidate in electrical engineering degree must be able to assemble and arrange PLC control program so that later can compete in industrial world. Therefore PLC is one of the compulsory courses that must be pursued. But in learning PLC encountered obstacles that students feel less interested in learning that they need to understand the language of logic, and require them to assemble the series of automation with inadequate equipment, so we think Simulation learning method is a learning method can improve the students' understanding of the situation or problem better. The purpose of this research is to know the effect of simulation learning method on students with high and low creativity level in PLC learning. The method used in this research is an experimental method. Result of this study is simulation learning method can improve learning result of PLC, but not maximal. PLC learning requires real work practices so as to provide accurate knowledge to every student.Based on these conclusions, the suggestion in PLC learning can use a learning method that uses work practices as a learning tool of PLC
\end{abstract}

\section{Introduction}

The rapid technological advancement of the last few years has brought about a change in the control system, and now the control system is automated, in which the development of microelectronic components can eventually produce a system that can replace the functions of tens or even hundreds of electromechanical relays with only one chip of microcontroller programmable programmable logic controller.[1] Programmable logic controller (PLC) is a microprocessor used to automate industry processes such as controlling and controlling a factory's engine.[2] PLC has input and output devices that are used to connect with external devices such as sensors, contactor relays and others. The programming language used to operate the PLC differs from the usual programming language. The language used is a ladder that contains only inputprocess-output.[3] As a candidate in electrical engineering degree must be able to assemble and arrange PLC control program so that later can compete in industrial 
world. Therefore PLC is one of the compulsory courses that must be pursued. But in learning PLC encountered obstacles that students feel less interested in learning that requires them to understand the language of logic, and requires them to assemble the series of automation with inadequate equipment and conventional learning methods.

Simulation learning method is a method of learning that gives the presentation of material that is impressed as a real situation and can be controlled and also the students are entitled to manipulate the situation or problem to improve students' understanding of the situation or problem better. Parisi argues that an important part of the simulation is to recreate or make certain parts of a real object or aspect into the imitation of moving parts or movable with a clone to produce something interactive.[4] Therefore we are challenged to investigate the influence of simulation method with trainer board which has been made as simple as possible so as to make it easier for students to understand so they can assemble and make program PLC.

The purpose of this research is to know the effect of simulation learning method on students with high and low creativity level in PLC learning. The application of simulation learning method by considering the level of creativity of students in the course of PLC is intended to provide tutorials to assemble and form a series of automation that can provide experience for students and can be a skill or knowledge so that after studying PLC courses students can achieve optimal learning outcomes [5] or understand the concept and practice of automatic control processes even in the implementation of the learning process has limitations on the availability of laboratory equipment. However, in the application of this method of learning, the problem was found that the availability of practicum tools was not adequate. In the application of this learning method, to overcome the problem of lack of tools in the laboratory we make a practical support tool in the form of board trainer to facilitate the practical work of students in learning PLC. Unlike other PLC laboratory equipment, the board coach is so simple that it can help students through the application of simulated learning methods to better understand the completion of PLC design, assembly and programming projects.[6] The renewal of the council coach makes the application of simulation learning methods appropriate for application in developing countries with various limitations in the field of learning facilities and infrastructure.

\section{Methods}

The method used in this research is an experimental method with care design at level $2 \times$ 2.Dependent variable is Student learning outcomes in the course of PLC, the independent variables are 1) learning methods consisting of project based learning methods and simulation learning methods, 2) the level of student creativity, differentiated with high and low creativity.

The population in this study is sixth-semester students majoring in electrical engineering education, faculty of Engineering Universitas Negeri Manado academic year 2014/2015 with total 80 people. The sample in this study followed the recommendation from Popham that high and low groups were selected by selecting $30 \%$ [7] from 80 students of which 24 students with high creativity 
divided by 2 , so 12 students entered the experimental class with the treatment of project-based learning methods and 12 other students entered the control class with Treatment of simulated learning method, as well as 24 students who have low creativity level. This research was conducted at the Department of Electrical Engineering faculty of Engineering Universitas Negeri Manado in Tondano which lasted for 1 semester which runs on the even semester from January to the beginning of July 2015.

The technique of collecting learning result data is obtained through the test of learning result which consists of $50 \%$ written test and $50 \%$ practice test. The written test is in form 30 objective questions, with weight 1 for correct answer and 0 for the wrong answer, while for practice test is taken through observation sheet with maximum score 3 for best condition and 0,6 for bad state, as well as techniques of collecting student creativity data obtained through a creativity questionnaire consisting of 30 statements using a scale of 1-5. Validity test is done in two forms, namely testing the validity of constructs/content and testing of empirical validity. Testing the validity of the constructs/contents is done with expert analysis and empirical validity testing with the correlation of grain scores with the total score of test results test.

Team experts for analysis the test of learning outcomes is: Prof. Dr. H. Sumual, M.Si, Dr. Ir. V. R. Palilingan, M.Eng, and for the instrument of creativity is Prof. Dr. Yufiarti and Dr. Syuul T. Karamoi, M.Si, Respondents expert review consists of Respondents were asked to provide an assessment of learning outcomes on the following aspects: 1) Question item according to indicator, 2) Problems are clearly defined, 3) The language domain, 4) The formulation of a sentence does not give rise to a double understanding, 5) Material compatibility. After testing the validity of the construct followed by empirical validity testing. The test of the instrument is carried out on the students majoring in electrical engineering education with the number of 30 students in the semester VIII who have passed the PLC courses. Implementation of test questions carried out before the implementation of the experiment and who conducted the trial is a researcher and assisted by a team of lecturers majoring in electrical engineering education. The formula used to test the validity of written test learning result is the correlation of biserial point, and for practice test is product moment correlation, and for creativity instrument is product moment correlation. The conclusion of the test results of validity of the instrument written test learning results are 30 valid questions and 2 invalid questions that are the number 25 and 29, and for practice test is stated all valid items, as well the results of validity test of creativity instrument there are 30 items valid and 6 invalid items are questioned number 6 , $7,8,11,30,34$. In this research, internal reliability test is done once and using one instrument the formula used for the written test is Kuder-Richardson 21, as well Reliability test used for product/practice test and creativity instrument is a coefficient of Alpha. The results of the reliability test of the written test show the high reliability because is the value of $\mathrm{r} 11=0.87884$, for product/practice test show high reliability because is the value of $\mathrm{r} 11=0.75369$, and creativity test showed the reliability is very high because the value of reliability test is 0.8187656 . 
Data analysis used in this research include descriptive analysis, prerequisite test analysis, and inferential analysis. Data to be analyzed with inferential statistics are assumed to be normally distributed. Normality test of data distribution is done by using Lilliefors test. Homogeneity measurements were performed to test data of groups A1B1, A2B1, A1B2, A2B2 using Bartlett test.

Hypothesis testing was done by variance analysis technique of two variants of ANAVA and continued with the advanced test of Tukey test, with the aim to test the influence of learning method and creativity level to the learning result.

\section{Results and Discussion}

\section{A. Data Description}

Summary of PLC learning outcome scores in this study for each group is presented in table 1 below.

From table 1, obtained the score of learning outcomes PLC 24 students who were taught by the method of simulation learning is in the range $57.3-76.3$ with an average score of $=66.4$; Median 65.2; Standard deviation 5,88; and variance 34.64. Furthermore, it is presented distribution of frequency of learning result of PLC of student group which is learned by simulation learning method in table 2 below.

Table 1. Summary Description of Research Data

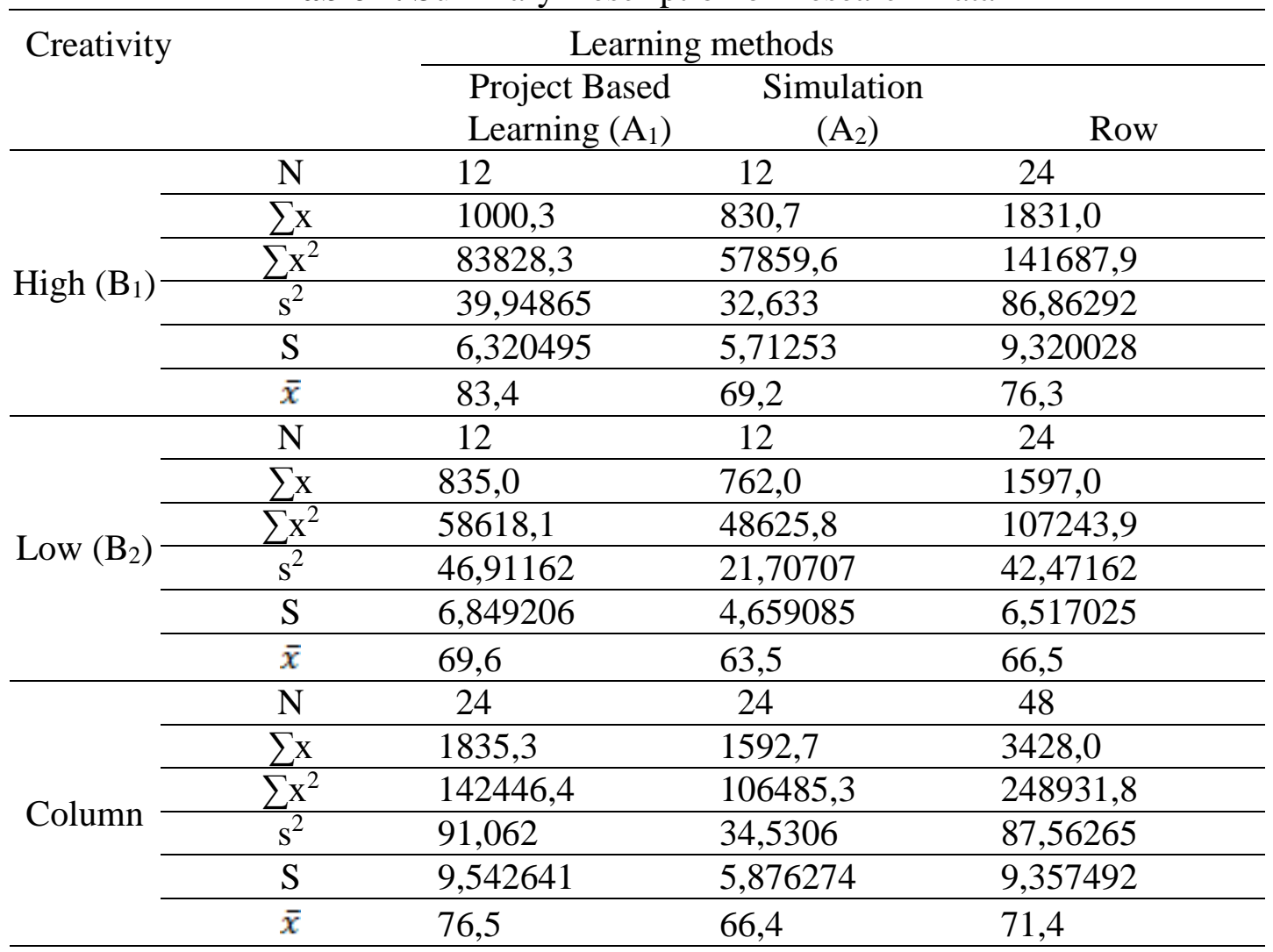


Journal of Educational Method and Technology Vol. 1 No. 2, September 2018

P-ISSN 2622-8459 E-ISSN 2622-8467

http://ejournal.unima.ac.id/index.php/jemtec

Table 2. Distribution of learning frequency of student learning PLC which is learned by simulation learning method.

\begin{tabular}{cccc}
\hline No & Interval Class & Absolute Frequency & Relative Frequency (\%) \\
\hline 1 & $57,0-60,9$ & 6 & $25 \%$ \\
\hline 2 & $61,0-64,9$ & 5 & $20,83 \%$ \\
\hline 3 & $65,0-68,9$ & 5 & $20,83 \%$ \\
\hline 4 & $69,0-72,9$ & 4 & $16,67 \%$ \\
\hline 5 & $73,0-76,9$ & 4 & $16,67 \%$ \\
\hline & SUM & 24 & 100 \\
\hline
\end{tabular}

Based on table 2, it can be described that the highest percentage is in the 1st class, where 6 or $25 \%$ of students score between 57.0 and 60.9. The frequency distribution of PLC learning scores in the group of students who were taught by simulation learning method is presented in the form of histogram as follows.

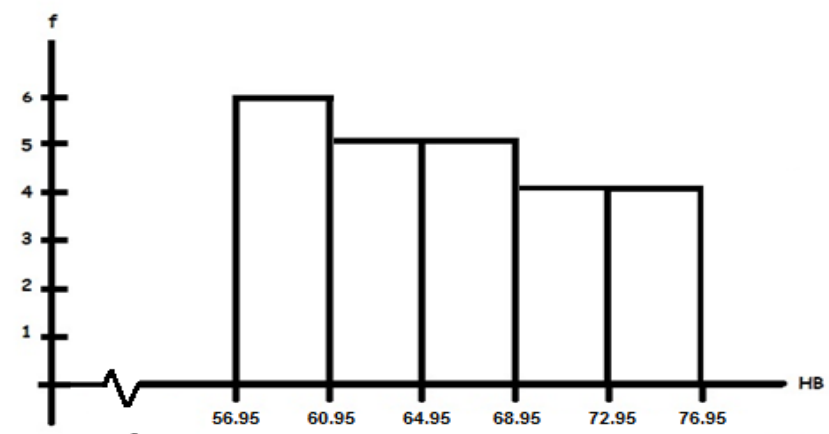

Figure 1. Histogram Score Learning Results PLC Students who are taught by the method of simulation learning

For more details, the learning outcomes of PLC students who are taught by simulation learning methods are separated by high creativity and low creativity categories. In the group of students with high creativity, PLC learning outcomes of 12 students were in the range $60-76.3$ with an average score of 69.2 Median 69.5 standard deviation 5.72 and variance 32.71. Semnetara in the group of students with low creativity, PLC learning outcomes of 24 students are in the range $57-72.7$ with average score $=63.5$ Median 63.3 Standard deviation 4.67 and variance 21.85. Furthermore, the data are presented in table 3 and table 4 .

Table 3. Frequency distribution of learning result of programmable logic controller (PLC) of student group that is learned by Simulation learning method and has high creativity

\begin{tabular}{cccc}
\hline No & Interval Class & Absolute Frequency & Relative Frequency (\%) \\
\hline 1 & $60,0-63,9$ & 2 & $16,67 \%$ \\
\hline 2 & $64,0-67,9$ & 4 & $33,33 \%$ \\
\hline 3 & $68,0-71,9$ & 1 & $8,33 \%$ \\
\hline 4 & $72,0-75,9$ & 3 & $25 \%$ \\
\hline 5 & $76,0-79,9$ & 2 & $16,67 \%$ \\
\hline & Jumlah & 12 & 100 \\
\hline
\end{tabular}


Table 4. Distribution of learning frequency programmable logic controller (PLC) group of students who were taught by learning method Simulation and have low creativity

\begin{tabular}{cccc}
\hline No & Interval Class & Absolute Frequency & Relative Frequency (\%) \\
\hline 1 & $57,0-60,9$ & 5 & $41,67 \%$ \\
\hline 2 & $60,9-64,9$ & 3 & $25 \%$ \\
\hline 3 & $65,0-68,9$ & 2 & $16,67 \%$ \\
\hline 4 & $70,0-73,9$ & 2 & $16,67 \%$ \\
\hline \multicolumn{2}{l}{ Jumlah } & 12 & 100 \\
\hline
\end{tabular}

Based on table 3 above, it can be described that the highest frequency is in the 2nd grade ie 4 or $33.33 \%$ of students get a score between 64.0 to 67.9 . The frequency distribution of PLC learning result scores in the student group which is taught by the method of simulation learning and has high creativity is presented in the form of histogram as follows.

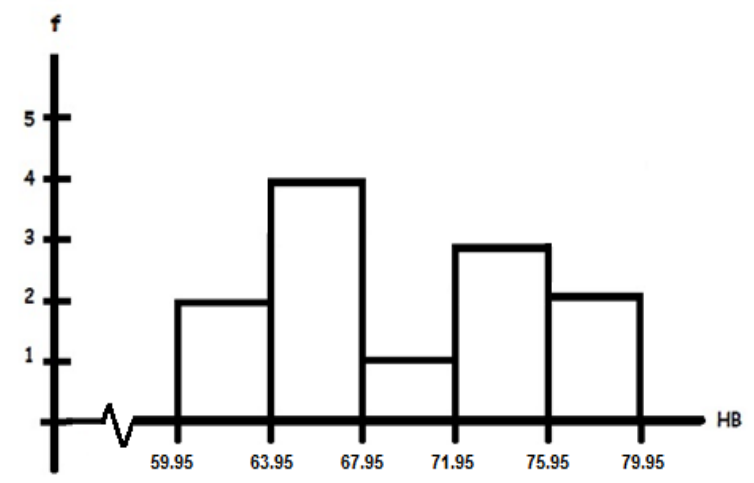

Figure 2. Histogram Score Learning Outcomes of Student with high creativity

Based on table 4, it can be described that the highest frequency is in the first grade of 5 or $41.67 \%$ of students score between 57.0 and 60.9. Frequency distribution of PLC learning outcomes in the group of students who were taught by simulation learning method and have low creativity presented in the form of histogram as follows

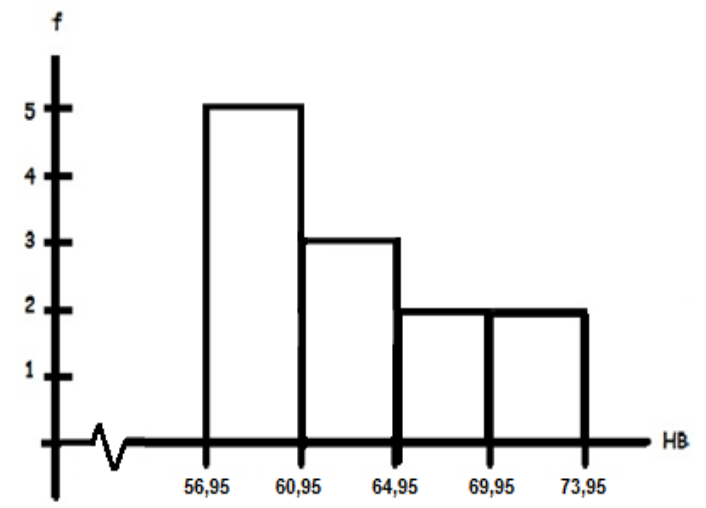

Figure 3. Histogram Score Learning Outcomes of Student with low creativity 


\section{B. Testing Analysis Requirements}

\section{Normality Test}

Normality test was performed on the score data of learning outcomes of programmable logic controller from each treatment group. Testing the normality of this data is done through Lilliefors test with significance level $\alpha=0,05$. The decision-making criterion accepts the null hypothesis that data comes from a normally distributed population if the Lo or $\mathrm{Lt}$ value is less than $\mathrm{L}_{\text {tabel }}$ at $\alpha=0.05$ ( $\mathrm{L}_{\text {count }}<\mathrm{L}_{\text {table }}$ ), otherwise if the Lo or $\mathrm{L}_{\text {count }}$ is greater than $\mathrm{L}_{\text {table }}$ at $\alpha=0,05$ $\left(\mathrm{L}_{\text {count }}>\mathrm{L}_{\text {table }}\right)$ then reject Ho or accept $\mathrm{H} 1$. The calculation results are presented in the following table.

Table 5. Normality test

\begin{tabular}{llccc}
\hline No & Sample Group & $\mathrm{L}_{\text {count }}$ & $\begin{array}{c}\mathrm{L}_{\text {table }} \\
(\alpha=0,05)\end{array}$ & Decision \\
\hline 1 & All Student & 0,1287 & 0,18085 & $\mathrm{~L}_{\text {count }}<\mathrm{L}_{\text {table }}$, Accept $\mathrm{H}_{0}$ \\
\hline 2 & $\begin{array}{l}\text { Student with } \\
\text { high Creativity }\end{array}$ & 0,1312 & 0,256 & $\mathrm{~L}_{\text {count }}<\mathrm{L}_{\text {table }}$, Accept $\mathrm{H}_{0}$ \\
\hline 3 & $\begin{array}{l}\text { Student with } \\
\text { low Creativity }\end{array}$ & 0,1693 & 0,256 & $\mathrm{~L}_{\text {count }}<\mathrm{L}_{\text {table }}$, Accept $\mathrm{H}_{0}$ \\
\hline
\end{tabular}

From Table 5. Normality test can be concluded that all data group get value of Lo or Lhitung smaller than Ltabel at $\alpha=0,05$ (Lhitung $<$ Ltabel) which means accept Ho hence can be concluded all group of data normal distribution or can be concluded all group of data comes from a normally distributed population. It thus meets the requirements for inferential statistical tests.

\section{Homogeneity Test}

The homogeneity test was conducted to determine whether response variables from each sample group had the same variance. Homogeneity test was performed using Bartlett Test. Hypothesis to be tested:

$\mathrm{H}_{0} \quad$ : The variance of both groups is the same / homogeneous

$\mathrm{H}_{1} \quad$ : The varians of both different groups / Not Homogeneous

The test is done at the level of significance $\alpha=0.05$ that is by comparing the value $\chi_{\text {count }}^{2}$ with $\chi_{\text {table }}^{2}$ with decision-making criteria: accept Ho (variance of both groups equals) if value $\chi_{\text {count }}^{2}<\chi_{\text {table }}^{2}$ on $\alpha=0,05$. The result of homogeneity calculation $\chi_{\text {count }}^{2}=1,690315634<\chi_{\text {table }}^{2}=7,82$ so it is concluded all populations have the same or homogeneous variance, thus the requirements of inferential statistical test are met.

\section{Hypothesis testing}

Testing of research hypothesis based on analysis of two-lane variance is presented in Table 6 , followed by simple simple test and done to the difference of result of learning programmable logic controller (PLC) between each factor of creativity. Tukey test calculation results are presented in Table 7. 
Based on the values in tables 6 and 7 that show the results of hypothesis testing is to examine the effect of learning methods based on high creativity level tehadap PLC learning results obtained value $\mathrm{q}_{\text {count }}=8.275$. Using the real level $\alpha$ $=0.05$ and $\mathrm{dk}=\mathrm{n}-2=24-2=22$, obtained $\mathrm{q}_{\text {table }}(0.05: 22)=3.44$. If both values of $\mathrm{q}$ are compared, then it turns out $\mathrm{q}_{\text {count }}=8.275>\mathrm{q}_{\text {table }}=3.44$, which means that in the group of students who have high creativity, student learning outcomes PLC taught by simulation learning method is lower than the results of student learning taught by the method of project based learning.

Table 6. Results of Two Paths ANAVA calculation

\begin{tabular}{lcccccc}
\hline \multirow{2}{*}{ Source Varians } & \multirow{2}{*}{ Dk } & \multirow{2}{*}{$\mathrm{JK}$} & \multirow{2}{*}{$\mathrm{RJK}$} & $\mathrm{F}_{\mathrm{c}}$ & \multicolumn{2}{c}{$\mathrm{F}_{\text {Table }}$} \\
\cline { 7 - 8 } $\begin{array}{l}\text { Between Columns } \\
\text { (Learning methods) }\end{array}$ & 1 & $\mathbf{1 2 2 6 , 1 4}$ & $\mathbf{1 2 2 6 , 1 4}$ & $\mathbf{3 4 , 7 2 * *}$ & $\mathbf{4 , 0 6}$ & $\mathbf{7 , 2 4}$ \\
\hline $\begin{array}{l}\text { Between Rows } \\
\text { (Creativity) }\end{array}$ & 1 & $\mathbf{1 1 4 0 , 7 5}$ & $\mathbf{1 1 4 0 , 7 5}$ & $\mathbf{3 2 , 3 0 * *}$ & $\mathbf{4 , 0 6}$ & $\mathbf{7 , 2 4}$ \\
\hline Interaction & 1 & $\mathbf{1 9 4 , 4 1}$ & $\mathbf{1 9 4 , 4 1}$ & $\mathbf{5 , 5 0 *}$ & $\mathbf{4 , 0 6}$ & $\mathbf{7 , 2 4}$ \\
\hline Between groups & 3 & $\mathbf{2 5 6 1 , 3}$ & $\mathbf{8 5 3 , 7 7}$ & $\mathbf{2 4 , 1 7 * *}$ & $\mathbf{2 , 8 2}$ & $\mathbf{4 , 2 6}$ \\
\hline In Group & 44 & $\mathbf{1 5 5 4 , 2}$ & $\mathbf{3 5 , 3 2}$ & - & - & - \\
\hline Total Reduction & 47 & $\mathbf{4 1 1 5 , 5}$ & - & - & - & - \\
\hline
\end{tabular}

Table 7. Results of Advanced Stage Analysis With Tukey Test

\begin{tabular}{|c|c|c|c|c|c|c|}
\hline \multirow{2}{*}{$\begin{array}{c}\text { Comparison } \\
\text { Group }\end{array}$} & \multirow{2}{*}{$\mathbf{n}$} & \multirow{2}{*}{$\mathbf{K}$} & \multirow{2}{*}{$\mathbf{D k}$} & \multirow{2}{*}{$\mathbf{Q}_{\mathbf{c}}$} & \multicolumn{2}{|c|}{$\mathbf{q}$} \\
\cline { 6 - 8 } & & & & & $\boldsymbol{\alpha} \mathbf{0 , 0 5}$ & $\boldsymbol{\alpha} \mathbf{0 , 0 1}$ \\
\hline $\mathrm{A}_{1} \mathrm{~B}_{1}$ and $\mathrm{A}_{2} \mathrm{~B}_{1}$ & 12 & 4 & 3.44 & 8,275 & 3,44 & 4,28 \\
\hline $\mathrm{A}_{1} \mathrm{~B}_{2}$ and $\mathrm{A}_{2} \mathrm{~B}_{2}$ & 12 & 4 & 3.44 & 3,555 & 3,44 & 4,28 \\
\hline
\end{tabular}

Similarly, the hypothesis test which tested the influence of the learning method based on the low creativity level on the learning outcomes of PLC obtained by the value of $\mathrm{q}_{\text {count }}=3,555$ using the real level $\alpha=0,05$ and $\mathrm{dk}=\mathrm{n}-2$ $=24-2=22$, obtained $\mathrm{q}_{\text {table }}(0.05: 22)=3.44$. If the two values of $\mathrm{q}$ are compared, then it turns out that $\mathrm{q}_{\text {count }}=3.555>\mathrm{q}_{\text {table }}(0,05: 22)=3,44$ it indicates that in the group of students who have low creativity, student learning outcomes PLC studied by simulation method is lower rather than the learning outcomes of PLC with project-based learning.

The results of this study indicate that in students with high and low creativity levels, the use of different learning methods gives a significant difference in the effect on the level of achievement of learning outcomes. However, based on existing quantitative data showed no significant difference because after the Tukey test the result $\mathrm{Q}_{\text {count }}>\mathrm{Q}_{\text {Table, meaning that the learning }}$ outcomes of students who have high and low creativity level with treatment using simulation learning method is lower than the group of students with treatment using the method of project based learning.

The results of this study indicate that the use of simulation learning methods can improve the learning outcomes [8] of PLC but not greater than the influence 
Journal of Educational Method and Technology Vol. 1 No. 2, September 2018

P-ISSN 2622-8459 E-ISSN 2622-8467

http://ejournal.unima.ac.id/index.php/jemtec

of the use of project-based learning methods [9]. It identifies that Programmable Logic Controller learning is not just a learning that relies on memory and practice on simulation but rather expects student involvement in real projects so as to produce knowledge as well as skills that can form a qualified person and able to compete in the industrial world as an undergraduate of electrical engineering education.

Simulation learning methods that use simulators have not been able to maximize PLC learning outcomes [10] because like a students are less challenged as they answer objective questions that choose from multiple answers. This is a challenge for lecturers to maximize their role as motivators and tutors in PLC learning using simulation learning methods to optimize learning outcomes with minimal equipment.

\section{Conclusion}

Simulation learning method can improve learning result of PLC, but not maximal. PLC learning requires real work practices so as to provide accurate knowledge to every student. Based on these conclusions, the suggestion in PLC learning can use a learning method that uses work practices as a learning tool of PLC.

\section{References}

[1] Pinnekamp F. Product automation. In Springer Handbook of Automation 2009 (pp. 545-558). Springer, Berlin, Heidelberg

[2] Ioannides MG. Design and implementation of PLC-based monitoring control system for induction motor. IEEE transactions on energy conversion. 2004 Sep;19(3):469-76.

[3] Erickson KT. Programmable logic controllers. IEEE potentials. 1996 Feb;15(1):14-7

[4] Parisi in F.Landriscina,Simulation and Learning. New york:Springer,2013. h.5

[5] Rais M. Development of Learning Media Based on Active Learning for Principles Design Subject to Conduct Students Intellectual Skills. International Seminar Reformulating theParadigm of Technical and Vocational Education 11 1221-1232. Badan Penerbit Universitas Negeri Makassar. 2017.

[6] Seke F R. Pengembangan Media Pembelajaran Programmable Logic Controller Menngunakan Omron Tipe CP1E. Edvokasi Jurnal Pendidikan teknologi dan Kejuruan. Vol. 6 Nomor 1. 2015: 24 -33.

[7] James P W. Modern Educational Measurement Englewood Cliff, NJ: Practice Hall, Inc. 1981. H.296

[8] Kiboss JK, Ndirangu M, Wekesa EW. Effectiveness of a computer-mediated simulations program in school biology on pupils' learning outcomes in cell theory. Journal of Science Education and Technology. 2004 Jun $1 ; 13(2): 207-13$

[9] Seke FR, Sumilat JM, Kembuan DR, Kewas JC, Muchtar H, Ibrahim N. Project-Based Learning in Programmable Logic Controller. InIOP 
Journal of Educational Method and Technology Vol. 1 No. 2, September 2018

P-ISSN 2622-8459 E-ISSN 2622-8467

http://ejournal.unima.ac.id/index.php/jemtec

Conference Series: Materials Science and Engineering 2018 Feb (Vol. 306, No. 1, p. 012042). IOP Publishing.

[10] Pea RD, Kurland DM. On the cognitive effects of learning computer programming. New ideas in psychology. 1984 Jan 1;2(2):137-68. 